\title{
Article \\ Spatiotemporal Variation in Groundwater Quality and Source Apportionment along the Ye River of North China Using the PMF Model
}

\author{
Chao Niu ${ }^{1}$, Qianqian Zhang ${ }^{2, *}$, Lele Xiao $^{1}$ and Huiwei Wang ${ }^{2}$ \\ 1 College of Geology and Environment, Xi'an University of Science and Technology, Xi'an 710054, China; \\ niuchao@xust.edu.cn (C.N.); xiaolele@xust.edu.cn (L.X.) \\ 2 Institute of Hydrogeology and Environmental Geology, Chinese Academy of Geological Sciences, \\ Shijiazhuang 050061, China; whuiwei@mail.cgs.gov.cn \\ * Correspondence: zhangqianqian@mail.cgs.gov.cn
}

Citation: Niu, C.; Zhang, Q.; Xiao, L.; Wang, H. Spatiotemporal Variation in Groundwater Quality and Source Apportionment along the Ye River of North China Using the PMF Model. Int. J. Environ. Res. Public Health 2022 19, 1779. https://doi.org/10.3390/ ijerph19031779

Academic Editor: Rui Zuo

Received: 22 November 2021

Accepted: 31 January 2022

Published: 4 February 2022

Publisher's Note: MDPI stays neutral with regard to jurisdictional claims in published maps and institutional affiliations.

Copyright: (C) 2022 by the authors. Licensee MDPI, Basel, Switzerland. This article is an open access article distributed under the terms and conditions of the Creative Commons Attribution (CC BY) license (https:// creativecommons.org/licenses/by/ $4.0 /)$.

\begin{abstract}
Groundwater quality deterioration has attracted widespread concern in China. In this research, the water quality index (WQI) and a positive matrix factorization (PMF) model were used to assess groundwater quality and identify pollution sources in the Ye River area of northern China. Research found that $\mathrm{TH}, \mathrm{SO}_{4}{ }^{2-}$, and $\mathrm{NO}_{3}{ }^{-}$were the main groundwater pollution factors in the $\mathrm{Ye}$ River area, since their exceeding standard rates were $78.13,34.38$, and $59.38 \%$, respectively. The main groundwater hydrochemical type has changed from $\mathrm{HCO}_{3}-\mathrm{Ca}(\mathrm{Mg})$ to $\mathrm{HCO}_{3} \cdot \mathrm{SO}_{4}-\mathrm{Ca}(\mathrm{Mg})$. These data indicated that the groundwater quality was affected by anthropogenic activities. Spatial variation in groundwater quality was mainly influenced by land use, whereas temporal variation was mainly controlled by rainfall. The WQI indicated that the groundwater quality was better in the flood season than in the dry season due to the diluting effect of rainfall runoff. Notably, farmland groundwater quality was relatively poor as it was affected by various pollution sources. Based on the PMF model, the main groundwater pollution sources were domestic sewage (52.4\%), industrial wastewater (24.1\%), and enhanced water-rock interaction induced by intensely exploited groundwater (23.6\%) in the dry season, while in the flood season they were domestic sewage and water-rock interaction $(49.6 \%)$, agriculture nonpoint pollution $(26.1 \%)$, and industrial wastewater and urban nonpoint pollution $(23.9 \%)$. In addition, the mean contribution of domestic sewage and industrial sewage to sampling sites in the dry season (1489 and $322.5 \mathrm{mg} / \mathrm{L}$, respectively) were higher than that in the flood season (1158 and $273.6 \mathrm{mg} / \mathrm{L}$, respectively). To sum up, the point sources (domestic sewage and industrial wastewater) remain the most important groundwater pollution sources in this region. Therefore, the local government should enhance the sewage treatment infrastructure and exert management of fertilization strategies to increase the fertilizer utilization rate and prevent further groundwater quality deterioration.
\end{abstract}

Keywords: groundwater quality; anthropogenic activities; source apportionment; water quality index; positive matrix factorization model

\section{Introduction}

Groundwater is a vital source of water for drinking, agriculture and industry, especially in arid and semi-arid areas [1]. However, with population growth and rapid industrialization, the quality of groundwater has deteriorated in recent years [2-4]. Groundwater quality has serious impacts on human and ecological health. Several studies have reported that high nitrate concentrations in drinking water were associated with the risk of "blue baby syndrome" $[5,6]$. In addition, drinking water containing high sulfate level can enhance mercury methylation [7].

The groundwater quality is largely affected by both the natural processes (such as hydrogeological conditions, lithology, groundwater-rock interaction, and the quality of 
water recharge) and anthropogenic activities (such as domestic sewage, industrial wastewater, agricultural fertilizers and pesticides, and over-exploitation of groundwater) [8-10]. Studies have indicated that anthropogenic pollutants such as chemical fertilizer, domestic sewage, seepage from landfills, and manure are the main sources of groundwater contamination [2,11,12]. Excessive stormwater runoff and irrigation water carried phosphorus, ammonia, and chloride infiltrates into groundwater, resulting in groundwater quality degradation $[13,14]$. Rapid urbanization and industrialization are additional major reasons for groundwater quality degradation [4,6].

Identifying the main pollution sources and formulating targeted preventive and control measures are effective tools to prevent the deterioration of groundwater quality. Several receptor models are currently used for apportioning sources in the environment. Among these, the absolute principal component score/multiple linear regression (APCS/MLR) model, the positive matrix factorization (PMF) model and the Unmix model have proven to be useful tools in source apportionment studies [15-18]. The PMF model has one important advantage; that is, that it weighs the uncertainty of each data point and applies a nonnegative constraint to the data, thereby ensuring that the source contributions are always positive $[19,20]$. Consequently, it has been recommended by the U.S. Environmental Protection Agency (USEPA) as a general apportionment modeling tool. This PMF model is widely used in atmospheric [21,22] and soil [15,23] studies to apportion pollution sources. Nowadays, it has been used to identify pollution sources in the water environment $[19,24]$.

The Ye River is a tributary of the Hutuo River located in the southwest of the Hebei Province, China. It is a mountain river originating in the Miao River in the Shouyang County of the Shanxi Province. This river flows from the southwest to northeast and empties into the Huangbizhuang Reservoir at Pingshan County. Groundwater is the main source for drinking water, agriculture, and industry in this area. However, with rapid urbanization and industrialization, the groundwater quality has been increasingly affected by human activities [13]. Nevertheless, relatively few studies have investigated groundwater quality and apportioned pollution sources in this region.

This study had the following three objectives: (1) To determine the spatial and seasonal variations in groundwater quality along the Ye River; (2) to assess the groundwater quality using the water quality index (WQI); (3) to identify the major groundwater pollution sources and quantify the proportional contributions using the PMF model. Collectively, these results will aid in the development of effective water-quality protection strategies and utilization of groundwater resources for this and other mountain river areas with different anthropogenic influences.

\section{Materials and Methods}

\subsection{Description of the Study Area}

The Ye River is located in the North China Plain. The study area spans from Yangquan County (Shanxi Province) to the Huangbizhuang Reservoir in Pingshan County (Hebei Province). The Ye River basin inclines from southwest to northeast and covers approximately $600 \mathrm{~km}^{2}$, and the total population is about 1.2 million. The study region has a semihumid and semi-arid monsoon climate, with an average annual precipitation of $500 \mathrm{~mm}$ (mostly falling from May to September) and a mean annual temperature of $20{ }^{\circ} \mathrm{C}$ [24]. Rainfall was $390.9 \mathrm{~mm}$ in 2018, and the rainfall in the rainy season was $344.4 \mathrm{~mm}$. The average flow of Ye River is $7.79 \mathrm{~m}^{3} / \mathrm{s}$ and $1.95 \mathrm{~m}^{3} / \mathrm{s}$ in the rainy season and dry season, respectively [25]. The main hydrochemical type of the Ye River is $\mathrm{SO}_{4} \cdot \mathrm{HCO}_{3}-\mathrm{Ca}(\mathrm{Mg})$ [26].

The main land use types include farmland (39.1\%), forest land (41.3\%), grassland $(13.2 \%)$, and construction land (5.2\%), along with surface water bodies (1.2\%) (Figure 1). In this region, the primary crops are wheat and corn. Nitrogen fertilizer is the primary agricultural fertilizer (mainly including urea, compound fertilizer, and manure). The main method of agricultural irrigation is flood irrigation. The main industrial types in the study area are coal mines, coal washing plants, metallurgy, machinery-manufacturing plants, cement plants, and power plants. 


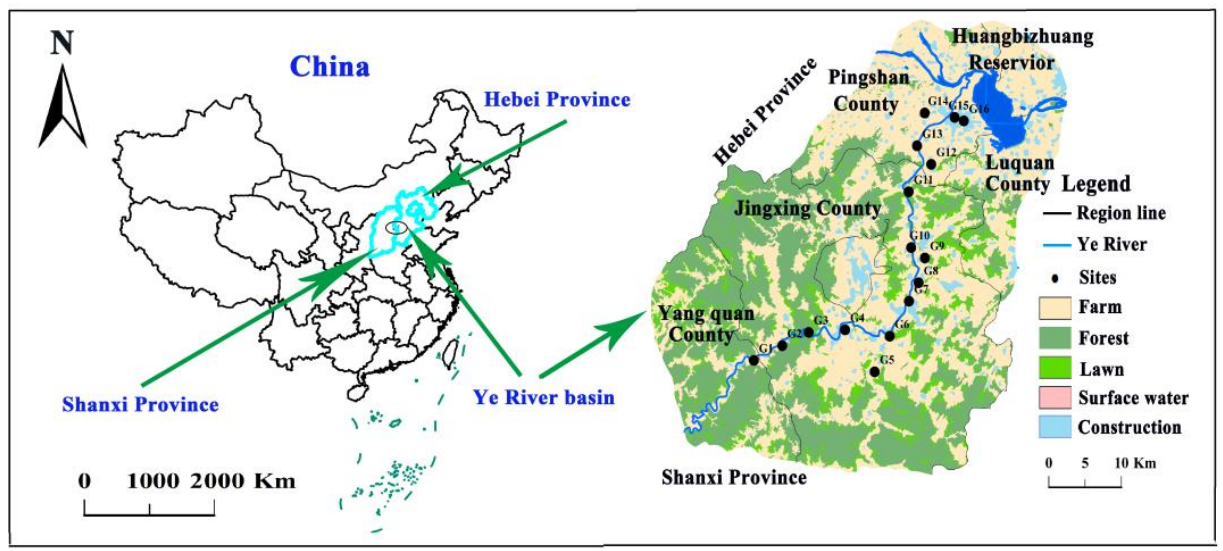

Figure 1. Groundwater sampling sites in the Ye River area.

The main aquifer forms part of the Quaternary aquifer system of the Hebei Plain and has an elevation that ranges between 53 and $195 \mathrm{~m}$ above the sea level [13]. The main minerals of the aquifer in this region are the limestone and dolomitic limestone. Its lithology consists of gravel, pebbles, coarse sand, and fine sand [11]. The principal type of groundwater in this basin is porous aquifer, and fractured aquifer is only distributed in mountainous areas. Following the topography, the groundwater flows from southwest to northeast. In this region, the aquifer has relatively high hydraulic conductivity $(\mathrm{k}=27.5-70.2 \mathrm{~m} / \mathrm{d})$ and the horizontal flow rate is estimated at $4 \mathrm{~m} /$ day [13]. Thus, groundwater is susceptible to pollutants. The groundwater is mainly recharged by precipitation, river inputs, and irrigation return, while manual exploitation is the main discharge mode. The depth of the groundwater table ranges from 3.2 to $23.4 \mathrm{~m}$ (the mean depth is $13.1 \mathrm{~m}$ ).

\subsection{Sample Collection and Analysis}

Groundwater samples were collected along the Ye River in April 2018 (dry season) and August 2018 (flood season), and comprised 16 sampling sites (According to the distance from the river (within $1 \mathrm{~km}$ ), the depth of the groundwater table $(<50 \mathrm{~m})$ and consideration of different land use types, 16 groundwater sampling wells were chosen, including 8 wells in village area, 3 wells in county area, and 5 wells in farmland area) (Figure 1). All the samples were collected in porous aquifer. All the wells chosen for groundwater sampling are commonly used for domestic and/or agricultural purposes, and the mean depth of wells is $26.9 \mathrm{~m}$ (ranging between 12 and $50 \mathrm{~m}$ ). Before collecting samples, these wells were purged for 5-10 min until the $\mathrm{pH}$ and $\mathrm{EC}$ of the groundwater were stable. Groundwater samples were extracted by pumping water from the wells. The $\mathrm{pH}$ and dissolved oxygen (DO) values were measured in the field using a multiparameter instrument $(\mathrm{HACH} \mathrm{HQ40d,}$ USA). All the water samples were filtered through $0.45 \mu \mathrm{m}$ membrane filters and then stored in $500 \mathrm{~mL}$ and a $1.5 \mathrm{~L}$ high-density polyethylene sampling bottles for water quality parameter analysis. Samples without preprocessing were used for anion analysis, while those used for cation and metal analysis were acidified with $\mathrm{HCl}$ to $\mathrm{pH}<2$.

The determination of anions (nitrate $\left(\mathrm{NO}_{3}{ }^{-}\right)$, nitrite $\left(\mathrm{NO}_{2}{ }^{-}\right)$, sulfate $\left(\mathrm{SO}_{4}{ }^{2-}\right)$, and chloride $\left(\mathrm{Cl}^{-}\right)$) was carried out using a spectrophotometer (Perkin-Elmer Lambda 35, Waltham, MA, USA). The cations (potassium $\left(\mathrm{K}^{+}\right)$, sodium $\left(\mathrm{Na}^{+}\right)$, calcium $\left(\mathrm{Ca}^{2+}\right)$, magnesium $\left(\mathrm{Mg}^{2+}\right)$ and ammonia $\left(\mathrm{NH}_{4}{ }^{+}\right)$) and metals (iron ( $\mathrm{Fe}$ ) and manganese $(\mathrm{Mn})$ ) were measured using an inductively coupled plasma-emission spectrometer (Agilent 7500ce ICP-MS, Tokyo, Japan); total dissolved solids (TDS) were measured using gravimetric methods, and the chemical oxygen demand (COD) was measured using alkaline permanganate oxidation. Total hardness (TH) was measured by the ethylene-diamine-tetraacetic acid (EDTA) titration method. The water chemistry was analyzed at the laboratory of the Groundwater Mineral Water and Environmental Monitoring Center at the Institute of Hydrogeology and Environmental Geology of the Chinese Academy of Geological Sciences. The chemical analysis results of 
all groundwater samples were examined by anion-cation balance test to ensure the relative error was less than $\pm 5 \%$.

\subsection{Data Analysis}

\subsubsection{Positive Matrix Factorization (PMF) Model}

In this study, EPA PMF (version 5.0) was used to apportion the dominant pollution sources of groundwater in the Ye River area. The model can be expressed as follows:

$$
x_{i j}=\sum_{k=1}^{p} g_{i k} f_{k j}+e_{i j}
$$

where $x_{i j}$ is the concentration of the $j$ th water quality parameter in the $i$ th sample; $g_{i k}$ is the contribution of the $k$ th source for $i$ number of samples; $f_{k j}$ is the concentration of the $j$ th water quality parameter in the $k$ th source. The residual error matrix $e_{i j}$ is obtained by minimizing the object function $Q$ :

$$
Q=\sum_{i=1}^{n} \sum_{j=1}^{m}\left(\frac{e_{i j}}{\mu_{i j}}\right)^{2}
$$

In this equation, $\mu_{i j}$ is the uncertainty in the $x_{i j}$ measurement, which is calculated from the method detection limit (MDL) and the standard deviations (SDs) of the surrogate standards. When the concentration of a water quality parameter was $\leq \mathrm{MDL}$, the uncertainty was calculated as:

$$
U n c=\frac{5}{6} \times M D L
$$

Otherwise, it was calculated as:

$$
U n c=\sqrt{(\sigma+c)^{2}+M D L^{2}}
$$

where $\sigma$ is the relative $\mathrm{SD}$ and $c$ is the level of the water-quality parameter. The EPA PMF 5.0 model was used in this study.

In this study, concentration data (including 14 water quality parameters for 16 water samples) and uncertainty data files (including sampling and analytical errors) were used as the input data for the PMF model to apportion the source contributions to groundwater quality in the Ye River area. Because the PMF model exhibits rotational ambiguity, the number of factors and the Fpeak values must be tested many times for different initial seeds to determine the variability in the PMF analysis. Different values of the rotational parameter Fpeak (between -1.5 and +1.5 , in steps of 0.1 ) were explored. When the number of factors was set at 3 and the Fpeak was -0.1 for dry and flood seasons, the runs of the PMF model were the best (the robust $Q$ value was lowest (24.69 and 15.78 for dry and flood seasons, respectively)) and passed the bootstrap test.

\subsubsection{The Water Quality Index (WQI)}

In this study, the WQI was used to assess the groundwater quality of the Ye River area. The WQI was calculated by assigning a weight $\left(W_{i}\right)$ to each water-quality indicator according to its relative importance in the overall quality of surface water for drinking purposes. Water-quality standards mainly referred to the Grade III standard for groundwater quality in China [27]. If this standard lacked a given indicator, we referred to the World Health Organization (2011) [28] standards. The assigned weight $\left(W_{i}\right)$ and the relative weight $\left(R W_{i}\right)$ for each indicator are given in Table 1 . The calculated WQI values were classified into five categories: excellent water (WQI $<50)$, good water (WQI $=50-100)$, poor water $(\mathrm{WQI}=100.1-200)$, very poor water $(\mathrm{WQI}=200.1-300)$, and unsuitable for human consumption (WQI > 300) [29]. 
Table 1. Relative weight of physicochemical parameters and water quality standard (all units of the parameters are $\mathrm{mg} / \mathrm{L}$ except $\mathrm{pH}$ ).

\begin{tabular}{cccc}
\hline Parameters & $\begin{array}{c}\text { Water Quality } \\
\text { Standards }\end{array}$ & Weight $\left(\boldsymbol{W}_{\boldsymbol{i}}\right)$ & $\begin{array}{c}\text { Relative Weight } \\
\left(\boldsymbol{R} \boldsymbol{W}_{\boldsymbol{i}}\right)\end{array}$ \\
\hline $\mathrm{pH}$ & $6.5-8.5$ & 4 & 0.082 \\
$\mathrm{TDS}$ & 1000 & 5 & 0.102 \\
$\mathrm{Na}^{+}$ & 200 & 3 & 0.061 \\
$\mathrm{Ca}^{2+}$ & 75 & 3 & 0.061 \\
$\mathrm{Mg}^{2+}$ & 50 & 3 & 0.061 \\
$\mathrm{Cl}^{-}$ & 250 & 5 & 0.102 \\
$\mathrm{SO}_{4}^{2-}$ & 250 & 5 & 0.102 \\
$\mathrm{HCO}_{3}^{-}$ & 500 & 1 & 0.020 \\
$\mathrm{NO}_{3}^{-}$ & 88.6 & 5 & 0.102 \\
$\mathrm{Fe}$ & 0.3 & 3 & 0.061 \\
$\mathrm{Mn}$ & 0.1 & 3 & 0.061 \\
$\mathrm{COD}$ & 3.0 & 5 & 0.102 \\
$\mathrm{TH}$ & 450 & 4 & 0.082 \\
$\mathrm{Sum}$ & & 58 & 1 \\
\hline
\end{tabular}

Note: The $\mathrm{Mg}^{2+}, \mathrm{Ca}^{2+}$ and $\mathrm{HCO}_{3}{ }^{-}$refer to the World Health Organization (2011) standards, the other parameters refer to the grade III standard for groundwater quality in China (GB/T 14848-2017).

The WQI was calculated as follows:

$$
\begin{gathered}
R W_{i}=\frac{W_{i}}{\sum_{i=1}^{n} W_{i}} \\
Q_{i}=\frac{C_{i}}{S_{i}} \times 100 \\
S I_{i}=W_{i} \times Q_{i} \\
W Q I=\sum S I_{i}
\end{gathered}
$$

where $Q_{i}$ is the quality rating, $C_{i}$ and $S_{i}$ represent the concentration $(\mathrm{mg} / \mathrm{L})$ and water quality standard of each water quality parameter, respectively, and $S I_{i}$ is the subindex of the $i$-th parameter.

\section{Results and Discussion}

\subsection{Groundwater Quality Properties of the Ye River Area}

Groundwater quality data are given in Table 2 . The groundwater $\mathrm{pH}$ was neutral to mildly alkaline (ranging from 6.91 to 7.87 , mean: 7.37) and all samples met the Grade III standard for groundwater quality in China [27]. The dissolved oxygen (DO) varied in the range of $2.67-9.45 \mathrm{mg} / \mathrm{L}$, with a mean value of $6.62 \mathrm{mg} / \mathrm{L}$. The mean groundwater TDS value was $866.80 \mathrm{mg} / \mathrm{L}$ and $31.25 \%$ of the samples surpassed the Grade III standard for groundwater quality in China [27]. The $\mathrm{NH}_{4}{ }^{+}$concentrations in groundwater in two seasons were below the detection limit (BDL: detection limit $=0.04 \mathrm{mg} / \mathrm{L}$ ). The mean cation concentrations were as follows, in decreasing order: $\mathrm{Ca}^{2+}(186.08 \mathrm{mg} / \mathrm{L})>\mathrm{Na}^{+}$ $(42.19 \mathrm{mg} / \mathrm{L})>\mathrm{Mg}^{2+}(39.27 \mathrm{mg} / \mathrm{L})>\mathrm{K}^{+}(2.22 \mathrm{mg} / \mathrm{L})>\mathrm{Fe}(0.129 \mathrm{mg} / \mathrm{L})>\mathrm{Mn}(0.006 \mathrm{mg} / \mathrm{L})$ The mean anion concentrations were: $\mathrm{HCO}_{3}{ }^{-}(312.32 \mathrm{mg} / \mathrm{L})>\mathrm{SO}_{4}{ }^{2-}(216.47 \mathrm{mg} / \mathrm{L})>$ $\mathrm{NO}_{3}{ }^{-}(134.60 \mathrm{mg} / \mathrm{L})>\mathrm{Cl}^{-}(96.38 \mathrm{mg} / \mathrm{L})$. The $\mathrm{SO}_{4}{ }^{2-}, \mathrm{NO}_{3}{ }^{-}, \mathrm{Cl}^{-}$and $\mathrm{Fe}$ accounted for $34.38,59.38,9.38$, and $6.25 \%$ of samples that surpassed the Grade III standard for groundwater quality in CHina [27]. Notably, the mean TH concentration reached $626.99 \mathrm{mg} / \mathrm{L}$ and $78.13 \%$ of the samples surpassed the Grade III standard for groundwater quality in China [27]. The above results show that the mean concentrations and exceeding standard rates of $\mathrm{TH}, \mathrm{SO}_{4}{ }^{2-}$, and $\mathrm{NO}_{3}{ }^{-}$were very high along the Ye River, indicating that its groundwater quality was generally affected by anthropogenic activities [30]. This result is consistent with previous studies. For example, researchers found that the main pollution factors of groundwater were $\mathrm{TH}, \mathrm{SO}_{4}{ }^{2-}$, and $\mathrm{NO}_{3}{ }^{-}$in the Hutuo River alluvial-pluvial 
fan [18]. Scholars also found that the groundwater in Songyuan City, Northeast China, has been affected by anthropogenic activities, resulting in mean $\mathrm{TH}$ and nitrate concentrations exceeding drinking water quality standards [31].

Table 2. Descriptive statistics of groundwater quality parameters along the Ye River.

\begin{tabular}{ccccccc}
\hline $\begin{array}{c}\text { Parameters } \\
(\mathbf{N}=\mathbf{3 2})\end{array}$ & Units & Range & Average & S.D. & Standard & $\begin{array}{c}\text { Below Standardsfor } \\
\text { All Sites (\%) }\end{array}$ \\
\hline $\mathrm{pH}$ & - & $6.91-7.87$ & 7.37 & 0.22 & $6.5-8.5$ & 0 \\
$\mathrm{DO}$ & $\mathrm{mg} / \mathrm{L}$ & $2.67-9.45$ & 6.62 & 1.67 & - & - \\
$\mathrm{TDS}$ & $\mathrm{mg} / \mathrm{L}$ & $499.23-1461.40$ & 866.80 & 259.10 & 1000 & 31.25 \\
$\mathrm{~K}^{+}$ & $\mathrm{mg} / \mathrm{L}$ & $0.55-5.67$ & 2.22 & 1.29 & - & - \\
$\mathrm{Na}^{+}$ & $\mathrm{mg} / \mathrm{L}$ & $8.88-174.97$ & 42.17 & 28.92 & 200 & 0 \\
$\mathrm{Ca}^{2+}$ & $\mathrm{mg} / \mathrm{L}$ & $106.62-324.65$ & 186.08 & 59.83 & - & - \\
$\mathrm{Mg}^{2+}$ & $\mathrm{mg} / \mathrm{L}$ & $11.42-88.35$ & 39.27 & 20.08 & - & - \\
$\mathrm{HCO}_{3}{ }^{-}$ & $\mathrm{mg} / \mathrm{L}$ & $176.20-462.10$ & 312.32 & 78.94 & - & - \\
$\mathrm{Cl}^{-}$ & $\mathrm{mg} / \mathrm{L}$ & $25.53-280.80$ & 96.38 & 62.32 & 250 & 9.38 \\
$\mathrm{SO}_{4}{ }^{2-}$ & $\mathrm{mg} / \mathrm{L}$ & $69.20-342.30$ & 216.47 & 66.79 & 250 & 34.38 \\
$\mathrm{NO}_{3}{ }^{-}$ & $\mathrm{mg} / \mathrm{L}$ & $15.07-376.50$ & 134.60 & 100.32 & 88.6 & 59.38 \\
$\mathrm{Fe}$ & $\mathrm{mg} / \mathrm{L}$ & $0.011-0.998$ & 0.129 & 0.199 & 0.3 & 6.25 \\
$\mathrm{Mn}$ & $\mathrm{mg} / \mathrm{L}$ & $0.001-0.045$ & 0.006 & 0.011 & 0.1 & 0 \\
$\mathrm{COD}$ & $\mathrm{mg} / \mathrm{L}$ & $0.36-1.41$ & 0.78 & 0.31 & 3.0 & 0 \\
$\mathrm{TH}$ & $\mathrm{mg} / \mathrm{L}$ & $370.79-1091.00$ & 626.99 & 194.33 & 450 & 78.13 \\
\hline
\end{tabular}

Note: $\mathrm{N}$ is the number of samples; standard is grade III standard for groundwater quality in China (GB/T 14848-2017).

\subsection{Groundwater Quality Assessment by Using Water Quality Index (WQI)}

The WQI classification of groundwater quality for the different seasons along the Ye River is shown in Table 3. The WQI ranged from 48.4 to 138.4. In the dry season, $6.2 \%$ of the groundwater samples were graded as excellent, $56.3 \%$ as good, and $37.3 \%$ as poor. In the flood season, $6.2 \%$ of the groundwater samples were graded as excellent, $87.5 \%$ as good, and only $6.3 \%$ as poor. Overall, the groundwater quality was better in the flood season than in the dry season, possibly due to the diluting effect of rainfall runoff on pollutants [18]. In addition, the sites with the worst water quality were farmland (accounting for 66.7 and $100 \%$ of the sites with poor water quality in the dry and flood seasons, respectively). This may be due to the fact that the farmland was mainly located near villages, and its groundwater quality may have been affected by the presence of mixed pollution sources such as domestic sewage, fertilizer, and manure [12].

Table 3. Water quality classification of different seasons along the Ye River.

\begin{tabular}{ccccc}
\hline \multirow{2}{*}{ WQI Range } & \multicolumn{2}{c}{ Dry Season } & \multicolumn{2}{c}{ Flood Season } \\
\cline { 2 - 5 } & $\begin{array}{c}\text { Number of } \\
\text { Samples }\end{array}$ & $\begin{array}{c}\text { Percentage of } \\
\text { Samples (\%) }\end{array}$ & $\begin{array}{c}\text { Number of } \\
\text { Samples }\end{array}$ & $\begin{array}{c}\text { Percentage of } \\
\text { Samples (\%) }\end{array}$ \\
\hline Excellent water & 1 & 6.2 & 1 & 6.2 \\
Good water & 9 & 56.3 & 14 & 87.5 \\
Poor water & 6 & 37.5 & 0 & 0.3 \\
Very poor water & 0 & 0 & 0 & 0 \\
Water unsuitable for & 0 & 0 & 16 & \\
drinking purposes & 16 & & & 0
\end{tabular}

\subsection{The Hydrochemical Characteristics of the Groundwater in the Ye River Area}

The hydrochemical components of groundwater are closely associated with the type and characteristics of strata lithology, as well as with the physical and chemical interactions occurring in the groundwater system [32,33]. In this study, the main minerals of the aquifer in this region are the limestone and dolomitic limestone. Thus, rainwater displaces a 
large amount of $\mathrm{HCO}_{3}{ }^{-}, \mathrm{Mg}^{2+}$ and $\mathrm{Ca}^{2+}$ from the strata in the process of replenishing groundwater. Therefore, the main hydrochemical type of groundwater in this area is mainly $\mathrm{HCO}_{3}-\mathrm{Ca}(\mathrm{Mg})$. A previous study found that the groundwater chemical type in the Shijiazhuang region was $\mathrm{HCO}_{3}-\mathrm{Ca}(\mathrm{Mg})$ before the 1950s [4]. In this study, the main groundwater chemical type was $\mathrm{HCO}_{3} \cdot \mathrm{SO}_{4}-\mathrm{Ca}(\mathrm{Mg})$ in the Ye River area. As shown in Figure 2, the $\mathrm{HCO}_{3} \cdot \mathrm{SO}_{4}-\mathrm{Ca}(\mathrm{Mg})$ chemical type accounted for 87.5 and $75.0 \%$ of groundwater samples in the dry and flood seasons, respectively, while the proportions of Cl-type groundwater were 18.6 and $31.3 \%$, respectively. Similar results were reported in a previous study by Ren et al. (2020). They reported that the main hydrochemical types of groundwater were $\mathrm{HCO}_{3} \cdot \mathrm{SO}_{4}-\mathrm{Ca}$ and $\mathrm{HCO}_{3} \cdot \mathrm{SO}_{4}-\mathrm{Ca} \cdot \mathrm{Mg}$, and $\mathrm{Cl}$-type water also accounted for certain proportions in this study area [34]. It is worth noting that the hydrochemical type of site 13 is $\mathrm{Cl}-\mathrm{Na}$ type in the flood season (Figure 2b), indicating that the site was severely affected by domestic sewage from the village. These data indicated that the groundwater quality in the Ye River area had undergone marked deterioration due to intensive human activities.

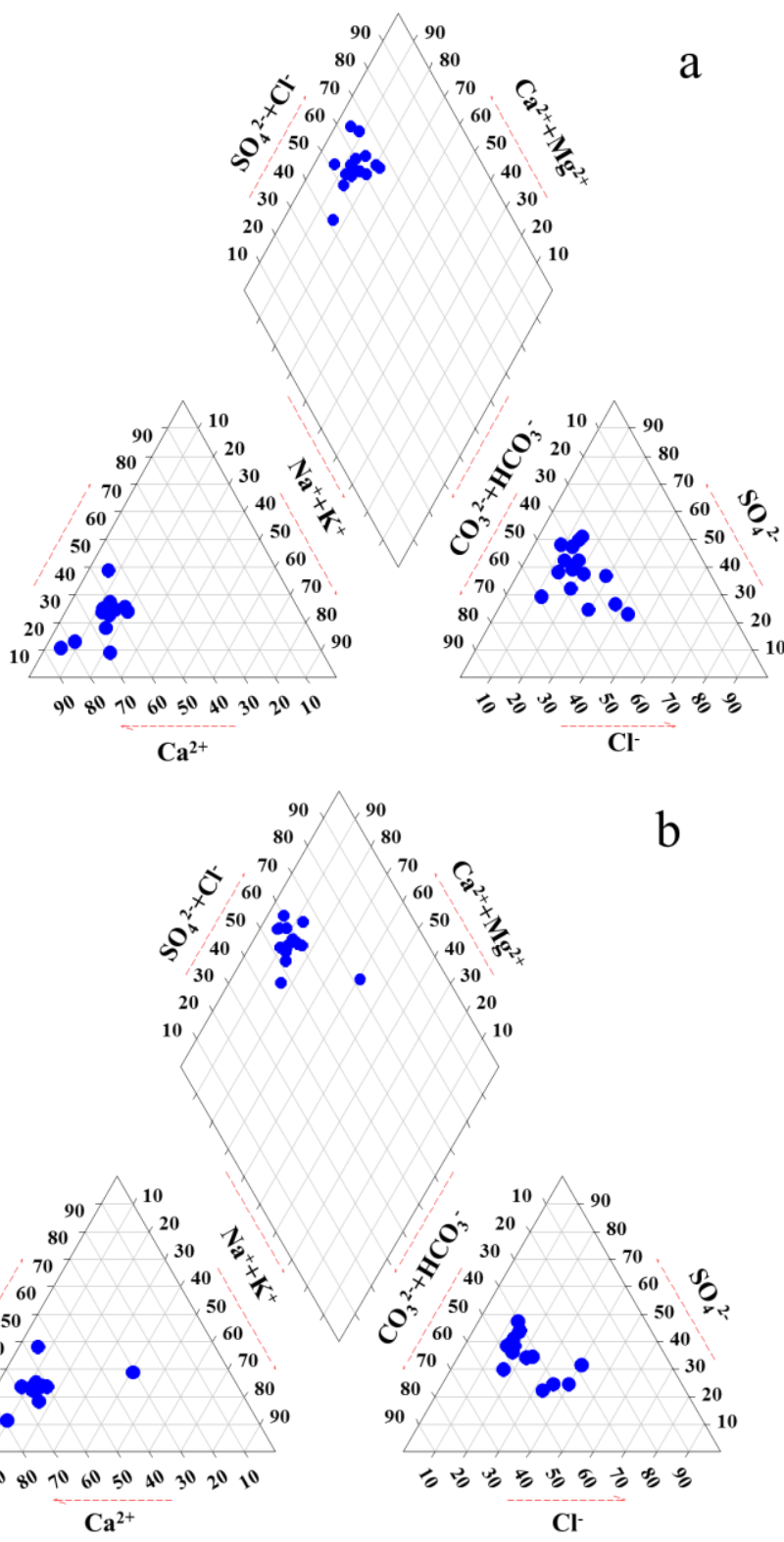

Figure 2. Piper diagram showing the chemical composition of the groundwater in the dry (a) and flood (b) season. 


\subsection{The Spatiotemporal Pattern of Groundwater Quality in the Ye River Area}

In this study, $\mathrm{pH}, \mathrm{NO}_{3}{ }^{-}, \mathrm{SO}_{4}{ }^{2-}$ and Fe were selected to assess the spatial and temporal variation in the groundwater quality. As shown in Figure $3 a, b, d$, no obvious spatial variation was observed in the mean $\mathrm{pH} \mathrm{SO}_{4}{ }^{2-}$, and Fe values. However, the mean groundwater $\mathrm{NO}_{3}{ }^{-}$concentration was higher in the farmland area than in the villages and county area (Figure 3c), possibly because the farmland area may have been affected not only by domestic sewage but also by agricultural fertilizers. Studies have shown that land use has an important effect on groundwater nitrate pollution [6]. In addition, land use changes may also affect the quality of the Ye River water. A previous study demonstrated that land use changes may lead strong impacts on the quality of river water [35]. This problem needs to be addressed in future studies.
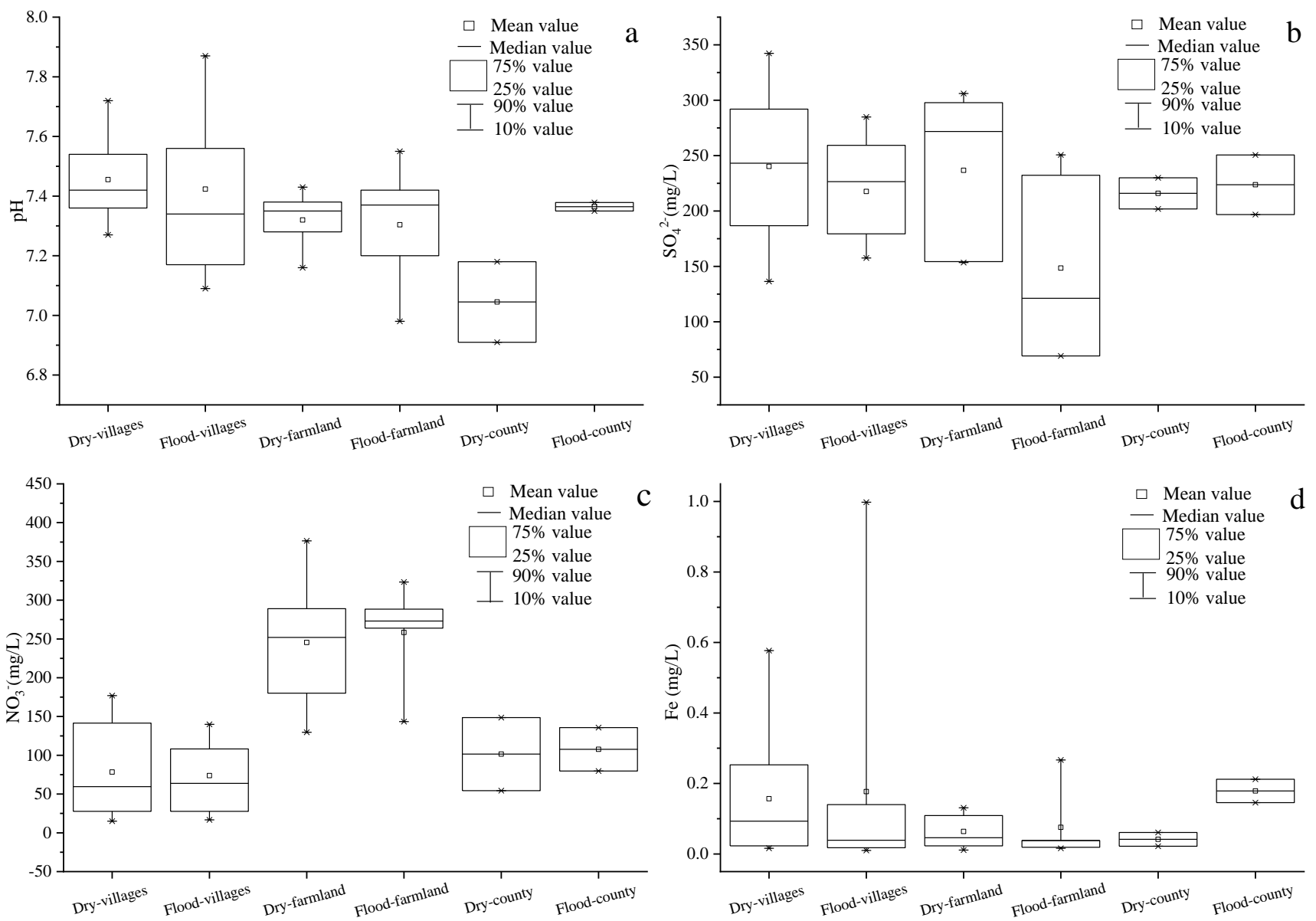

Figure 3. Spatial-temporal variations of (a) $\mathrm{pH}$; (b) $\mathrm{SO}_{4}{ }^{2-}$; (c) $\mathrm{NO}_{3}{ }^{-}$, and (d) Fe in groundwater of the Ye River area (The number of samples in Figure 3a-d are all 32).

In the Ye River area, temporal variations in the groundwater quality are likely to be mainly influenced by rainfall. As shown in Figure 3, no obvious temporal variation in $\mathrm{pH}$ was detected in the villages and farmland region (Figure 3a), which is likely because $\mathrm{pH}$ can be affected by multiple factors [36]. However, in the county region, $\mathrm{pH}$ in the flood season was slightly higher than in the flood season. The mean $\mathrm{SO}_{4}{ }^{2-}$ and Fe concentrations were higher in the dry season than in the flood season (except for Fe in the county region) (Figure 3b,d), which may be closely related to the dilution effect of rainfall [37]. However, the mean $\mathrm{NO}_{3}{ }^{-}$concentration in the farmland area in the flood season was marginally higher than that in the dry season (Figure 3c). This may be due to the fact that rainfall runoff carries large amounts of agricultural fertilizer, which infiltrates the groundwater. 


\subsection{Identifying the Groundwater Pollution Sources Using the PMF Model}

Three factors were identified in the dry and flood seasons using the PMF model. As shown in Table 4, in the dry season, Factor 1 explained $52.37 \%$ of the total water quality parameters and was associated with relatively high concentrations of TDS, $\mathrm{K}^{+}, \mathrm{Na}^{+}$, $\mathrm{Ca}^{2+}, \mathrm{Mg}^{2+}, \mathrm{SO}_{4}{ }^{2-}, \mathrm{NO}_{3}{ }^{-}, \mathrm{Cl}^{-}, \mathrm{COD}$, and $\mathrm{TH}$. Nitrate in groundwater may be mainly derived from chemical fertilizer, domestic sewage, industrial wastewater, soil nitrogen, and atmospheric deposition [38]. Domestic sewage may be the main source of $\mathrm{NO}_{3}{ }^{-}$pollution in groundwater in the dry season. In the Ye River basin, especially in mountain areas, most villages do not have a constructed network of sewage pipes, and their domestic sewage drains directly into the nearby river. Previous study has confirmed that there is a close hydraulic connection between groundwater and river water in the region, and the relationship between them is river water to replenish groundwater [26]. Furthermore, the formation lithology in this area is coarse. Thus, domestic sewage seeped into the aquifer easily. In the dry season, there is relatively little rainfall (the rainfall was $46.5 \mathrm{~mm}$ in 2018), and the $\mathrm{NO}_{3}{ }^{-}$concentration $(8.94 \mathrm{mg} / \mathrm{L})$ in rainfall is lower [11]; consequently, atmospheric deposition was not a main source of groundwater $\mathrm{NO}_{3}{ }^{-}$. Furthermore, in the dry season, chemical fertilizers may not have a significant effect on groundwater nitrate levels because they could not permeate into the groundwater in the absence of rainfall runoff and agricultural irrigation (Agricultural irrigation is seldom carried out in this time (January-April) in the study area). Chloride in groundwater can originate both from human activities (such as domestic sewage, industrial wastewater, chemical fertilizers, and road deicing salt) and natural sources (such as oceans, atmospheric deposition, and the weathering of evaporite rocks (halite)) [39]. In the Ye River basin, the higher concentration of $\mathrm{Cl}^{-}$in groundwater may have originated primarily from domestic sewage as chloride fertilizer was rarely applied, and the $\mathrm{Cl}^{-}$concentration in rainfall $(2.28 \mathrm{mg} / \mathrm{L})$ was low [11] Furthermore, this region is far from the sea. Road deicing salt is mainly used for urban roads and it does not directly affect the groundwater in the Ye River area. This indicates that $\mathrm{Cl}^{-}$also mainly originated from domestic sewage. Based on the above analysis, Factor 1 represents domestic sewage pollution (point source).

Table 4. Source profiles obtained from the PMF model.

\begin{tabular}{|c|c|c|c|c|c|c|}
\hline \multirow{2}{*}{ Parameters } & \multicolumn{3}{|c|}{ Dry Season } & \multicolumn{3}{|c|}{ Flood Season } \\
\hline & Factor 1 & Factor 2 & Factor 3 & Factor 1 & Factor 2 & Factor 3 \\
\hline $\mathrm{pH}$ & 0.63 & 0.96 & 5.75 & 4.74 & 1.83 & 0.65 \\
\hline TDS & 597.69 & 94.13 & 91.27 & 294.79 & 382.46 & 67.19 \\
\hline $\mathrm{K}^{+}$ & 0.85 & 0.35 & 0.14 & 0.41 & 0.71 & 0.14 \\
\hline $\mathrm{Na}^{+}$ & 24.19 & 3.69 & 4.49 & 10.83 & 7.07 & 3.91 \\
\hline $\mathrm{Ca}^{2+}$ & 122.94 & 21.69 & 18.57 & 108.66 & 29.99 & 14.56 \\
\hline $\mathrm{Mg}^{2+}$ & 21.71 & 3.60 & 2.93 & 16.12 & 3.46 & 3.56 \\
\hline $\mathrm{HCO}_{3}{ }^{-}$ & 31.75 & 47.35 & 218.73 & 151.88 & 93.43 & 25.93 \\
\hline $\mathrm{Cl}^{-}$ & 39.12 & 6.09 & 8.13 & 35.09 & 18.36 & 10.46 \\
\hline $\mathrm{SO}_{4}^{2-}$ & 123.51 & 58.81 & 24.68 & 72.13 & 19.29 & 52.45 \\
\hline $\mathrm{NO}_{3}^{-}$ & 28.01 & 7.82 & 8.58 & 18.75 & 11.54 & 2.24 \\
\hline $\mathrm{Fe}$ & 0.01 & 0.07 & 0.02 & 0.02 & 0.00 & 0.10 \\
\hline Mn & 0.001 & 0.003 & 0.002 & 0.001 & 0.002 & 0.003 \\
\hline COD & 0.39 & 0.22 & 0.06 & 0.27 & 0.09 & 0.45 \\
\hline $\mathrm{TH}$ & 426.75 & 69.75 & 65.66 & 389.49 & 95.70 & 50.81 \\
\hline $\begin{array}{l}\text { Possible } \\
\text { sources }\end{array}$ & $\begin{array}{l}\text { Domestic } \\
\text { sewage }\end{array}$ & $\begin{array}{l}\text { Industrial } \\
\text { sewage }\end{array}$ & $\begin{array}{l}\text { Water-rock } \\
\text { interaction }\end{array}$ & $\begin{array}{c}\text { Domestic } \\
\text { sewage and } \\
\text { water-rock } \\
\text { interaction }\end{array}$ & $\begin{array}{l}\text { Agriculture } \\
\text { nonpoint } \\
\text { pollution }\end{array}$ & $\begin{array}{c}\text { Industrial } \\
\text { wastewater } \\
\text { and urban } \\
\text { nonpoint } \\
\text { pollution }\end{array}$ \\
\hline $\begin{array}{l}\text { Contribution } \\
(\%)\end{array}$ & 52.37 & 24.12 & 23.51 & 49.55 & 26.12 & 23.94 \\
\hline
\end{tabular}


In the dry season, Factor 2 explained $24.12 \%$ of the total water-quality parameters, and it was associated with relatively high concentrations of Fe and $\mathrm{Mn}$ and moderate concentrations of $\mathrm{SO}_{4}{ }^{2-}$. Higher $\mathrm{Fe}$ and $\mathrm{Mn}$ concentrations are indicative of pollution by metals and metallic compounds and they could come from industrial effluents [40]. Indeed, the G10 site is located near an industrial park and has the greatest concentration of Fe $(0.577 \mathrm{mg} / \mathrm{L})$ and $\mathrm{Mn}(0.045 \mathrm{mg} / \mathrm{L}) . \mathrm{High} \mathrm{SO}_{4}{ }^{2-}$ concentrations in groundwater are thought to originate from both natural and anthropogenic sources, such as atmospheric deposition, the weathering of sulfide-bearing minerals and evaporite minerals, fertilizer, and domestic and industrial wastewater [41,42]. In the Ye River basin, domestic sewage and industrial wastewater were likely the greatest sources of $\mathrm{SO}_{4}{ }^{2-}$. This is because the domestic sewage was discharged untreated, and there were several coal mines and coal washing plants located near the Ye River. The wastewater from coal washing was directly discharged into the Ye River, and the wastewater would inevitably have infiltrated into the groundwater. Chemical fertilizers and rainfall were not the main sources of $\mathrm{SO}_{4}{ }^{2-}$ in groundwater, because sulfur fertilizer was rarely applied and the $\mathrm{SO}_{4}{ }^{2-}$ concentration in rainfall was low (5.89-37.9 mg/L) [43]. Considering that Factor 1 stands for domestic sewage pollution, Factor 2 is accordingly considered to denote industrial wastewater pollution (point source).

In the dry season, Factor 3 explained $23.51 \%$ of the total water-quality parameters. This factor is associated with relatively high $\mathrm{pH}$ levels and high concentrations of $\mathrm{HCO}_{3}{ }^{-}$, and moderate concentrations of TDS, $\mathrm{TH}$, and $\mathrm{Ca}^{2+}$. Studies have reported that higher concentrations of $\mathrm{HCO}_{3}{ }^{-}, \mathrm{TH}$, and $\mathrm{Ca}^{2+}$ in groundwater may result from enhanced waterrock interactions and accelerated rock dissolution (e.g., limestone and dolomite) [44]. In the Ye River basin, groundwater has been intensely exploited due to the massive use of water in industry and agriculture, which enhanced cation exchange processes, leading to the increase in $\mathrm{TH}$ and $\mathrm{Ca}^{2+}$ levels in the groundwater. In the Ye River basin, the higher concentration of $\mathrm{HCO}_{3}{ }^{-}$and $\mathrm{Ca}^{2+}$ was mainly due to the dissolution of limestone, expressed as Equation (9)

$$
\mathrm{CaCO}_{3}+\mathrm{H}^{+}=\mathrm{Ca}^{2+}+\mathrm{HCO}_{3}^{-}
$$

Therefore, Factor 3 represents enhanced water-rock interaction induced by intensely exploited groundwater.

In the flood season, Factor 1 explained $52.37 \%$ of the total water-quality parameters and was associated with relatively high $\mathrm{pH}$ levels and concentrations of $\mathrm{Na}^{+}, \mathrm{Ca}^{2+}, \mathrm{Mg}^{2+}$, $\mathrm{SO}_{4}{ }^{2-}, \mathrm{NO}_{3}{ }^{-}, \mathrm{Cl}^{-}, \mathrm{HCO}_{3}{ }^{-}$, and $\mathrm{TH}$, as well as moderate concentrations of TDS and $\mathrm{K}^{+}$. Thus, Factor 1 was consistent with domestic sewage and water-rock interactions. Factor 2 explained $26.12 \%$ of the total water-quality parameters and was associated with relative greater concentrations of TDS and $\mathrm{K}^{+}$, and moderate concentrations of $\mathrm{NO}_{3}{ }^{-}$. As mentioned above, $\mathrm{NO}_{3}{ }^{-}$in groundwater can originate from chemical fertilizer [33]. In the flood season, rainfall runoff lixiviates chemical fertilizer into groundwater, thereby increasing its $\mathrm{NO}_{3}{ }^{-}$concentration. In addition, agricultural runoff has been reported to contain large amounts of ions (such as $\mathrm{K}^{+}$) [45]. Therefore, Factor 2 represents agricultural nonpoint pollution. Factor 3 explained $23.94 \%$ of the total water-quality parameters and was associated with relatively greater concentrations of $\mathrm{Fe}, \mathrm{Mn}$, and COD, and moderate concentrations of $\mathrm{SO}_{4}{ }^{2-}$. As discussed in the previous paragraph, the $\mathrm{Fe}, \mathrm{Mn}$, and $\mathrm{SO}_{4}{ }^{2-}$ in the groundwater were mainly derived from industrial wastewater. However, COD in groundwater may also originate from road runoff (urban nonpoint pollution), and COD has been reported to be a major pollutant in urban roads [46]. Accordingly, Factor 3 is considered to denote to industrial wastewater and urban nonpoint pollution.

\subsection{Source Contribution Using the PMF Model}

3.6.1. Estimated Contribution (mg/L) of Each Source to 16 Sampling Sites

Figure 4 shows the mean contributions (mg/L) of three sources at 16 sampling sites based on the output of the PMF model. In addition, Table 5 summarized the main character- 
istics of each site. On the whole, the mean contribution of domestic sewage and industrial sewage to 16 sampling sites in the dry season (1489 and $322.5 \mathrm{mg} / \mathrm{L})$ was higher than that in the flood season (1158 and $273.6 \mathrm{mg} / \mathrm{L})$, which is mainly due to the dilution of excessive rainfall in the flood season (Figure 4S1) [18]. The contribution rate of domestic sewage during the dry and flood season was higher in the village sites (1646 and $1277 \mathrm{mg} / \mathrm{L})$ than that in farmland sites (1589 and $1155 \mathrm{mg} / \mathrm{L})$ and county sites (1398 and $873.2 \mathrm{mg} / \mathrm{L})$, which may be due to the domestic sewage substandard emissions in the village region. However, the spatial variation at different land use patterns in the dry and flood season showed that the contribution rate of industrial sewage in village sites (404.2 and $384.4 \mathrm{mg} / \mathrm{L})$ was higher than that in county sites (245.4 and $220.0 \mathrm{mg} / \mathrm{L})$ and farmland sites $(147.3$ and $95.6 \mathrm{mg} / \mathrm{L})$. In addition, in the dry season, the mean contribution of water-rock interaction at 16 sites was higher in the village sites $(810.8 \mathrm{mg} / \mathrm{L})$ than that of the county $(116.6 \mathrm{mg} / \mathrm{L})$ and farmland sites $(115.5 \mathrm{mg} / \mathrm{L})$. The mean contribution of agricultural nonpoint pollution at 16 sites in the flood season in the farmland sites $(970.5 \mathrm{mg} / \mathrm{L})$ was higher than that in the village sites $(880.5 \mathrm{mg} / \mathrm{L})$ and county sites $(379.0 \mathrm{mg} / \mathrm{L})$. It is noteworthy that the highest contribution of agricultural nonpoint pollution and urban nonpoint pollution was from site 10 (agricultural area) and site 11 (county area) (6903 and $3103 \mathrm{mg} / \mathrm{L}$ ), respectively. This was closely related to the excessive application of chemical fertilizer in agricultural areas and the heavy traffic in urban areas.
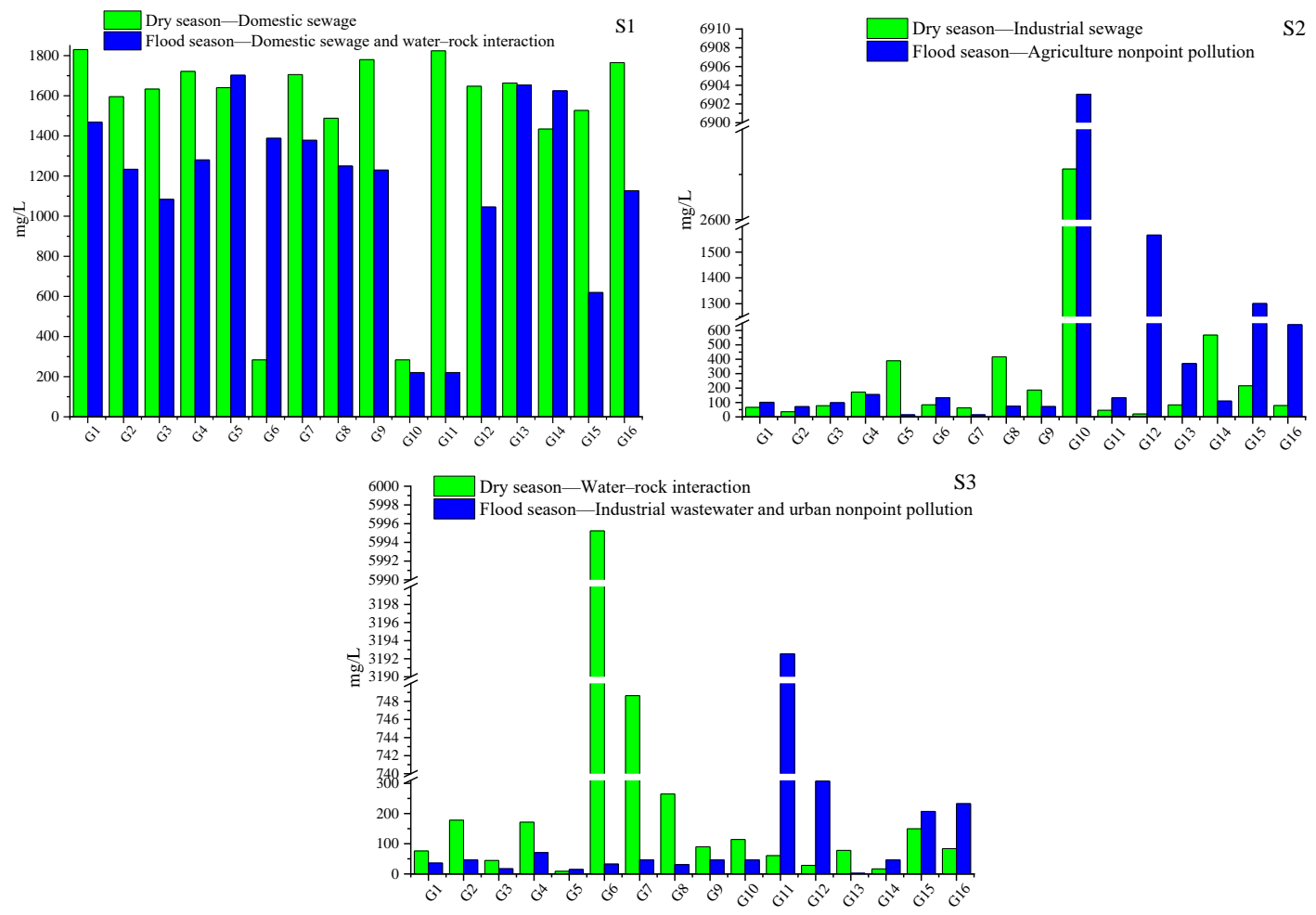

Figure 4. Estimated contributions $(\mathrm{mg} / \mathrm{L})$ from each source at the sampling sites during the dry and flood seasons obtained by the PMF model (Note: (S1): Source 1; (S2): Source 2; (S3): Source 3).

\subsubsection{Estimated Contribution Rate (\%) of Each Source to 14 Water Quality Variables}

The contribution proportion of each source to each groundwater quality parameters was calculated using the PMF model. As shown in Figure 5, in the dry season, most of the water-quality parameters were affected by domestic sewage $\left(76.3 \%\right.$ of TDS, $63.5 \%$ of $\mathrm{K}^{+}$, $74.7 \%$ of $\mathrm{Na}^{+}, 75.3 \%$ of $\mathrm{Ca}^{2+}, 76.9 \%$ of $\mathrm{Mg}^{2+}, 73.3 \%$ of $\mathrm{Cl}^{-}, 59.7 \%$ of $\mathrm{SO}_{4}{ }^{2-}, 63.1 \%$ of $\mathrm{NO}_{3}{ }^{-}$, $58.0 \%$ of $\mathrm{COD}$ and $75.9 \%$ of $\mathrm{TH})$ industrial sewage $(73.0 \%$ of $\mathrm{Fe}, 58.2 \%$ of $\mathrm{Mn}, 32.3 \%$ of $\mathrm{COD}$ and $28.4 \%$ of $\mathrm{SO}_{4}{ }^{2-}$ ) and water-rock interaction $\left(78.4 \%\right.$ of $\mathrm{pH}$ and $73.4 \%$ of $\mathrm{HCO}_{3}{ }^{-}$ and $31.5 \%$ of $\mathrm{Mn}$ ). 
Table 5. Statistic table of the main characteristics of each site.

\begin{tabular}{ccccc}
\hline Sites & Land Use & $\begin{array}{c}\text { Depth of the } \\
\text { Well }(\mathbf{m})\end{array}$ & $\begin{array}{c}\text { Depth of } \\
\text { Groundwater }(\mathbf{m})\end{array}$ & Pollution Sources \\
\hline G01 & Village & 20 & 9.6 & Sewage and Manure \\
G02 & Agriculture & 30 & 10.5 & Fertilizer \\
G03 & Village & 40 & 12.5 & Sewage and Manure \\
G04 & County & 35 & 16.6 & Sewage and coal mine effluent \\
G05 & Village & 18 & 10.3 & Sewage and wastewater \\
G06 & Village & 33 & 15.1 & Sewage \\
G07 & Village & 15 & 3.2 & Sewage and coal mine effluent \\
G08 & Agriculture & 25 & 18.5 & Fertilizer and sewage \\
G09 & Agriculture & 20 & 12.2 & Fertilizer and Manure \\
G10 & Village & 12 & 6.5 & Sewage and wastewater \\
G11 & Village & 28 & 15.3 & Sewage and manure \\
G12 & Agriculture & 22 & 14.8 & Fertilizer \\
G13 & Village & 12 & 8.7 & Sewage \\
G14 & Agriculture & 25 & 9.5 & Fertilizer \\
G15 & County & 50 & 22.5 & Sewage \\
G16 & County & 45 & 23.4 & Sewage \\
\hline
\end{tabular}
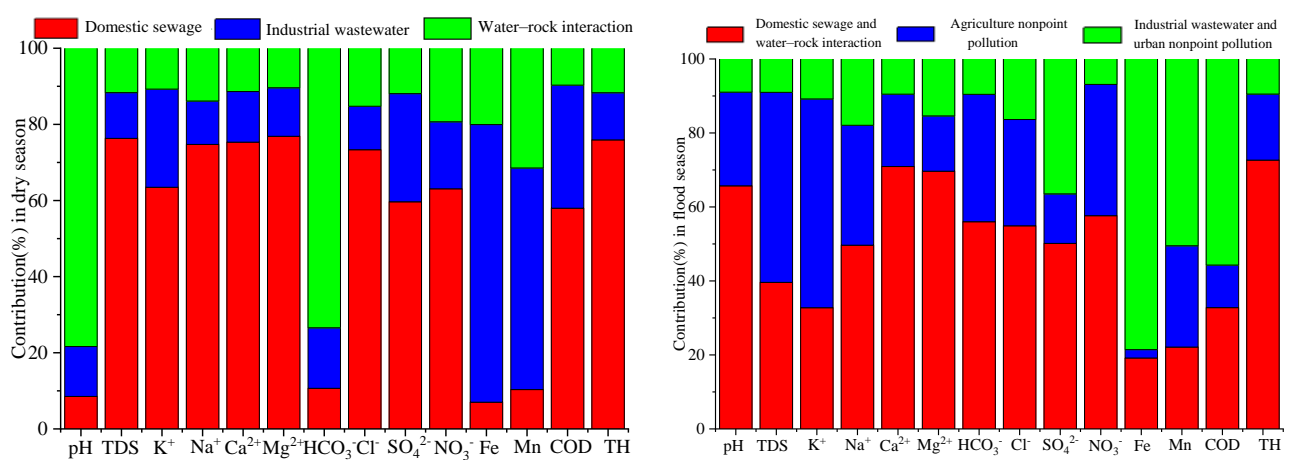

Figure 5. Source contribution (in \%) of each variable in the dry and flood seasons in the Ye River basin.

In the flood season, water-quality parameters were affected by domestic sewage and water-rock interaction $\left(65.7 \%\right.$ of $\mathrm{pH}, 49.7 \%$ of $\mathrm{Na}^{+}, 70.9 \%$ of $\mathrm{Ca}^{2+}, 69.7 \%$ of $\mathrm{Mg}^{2+}, 50.1 \%$ of $\mathrm{SO}_{4}{ }^{2-}, 57.6 \%$ of $\mathrm{NO}_{3}{ }^{-}, 54.9 \%$ of $\mathrm{Cl}^{-}, 56.0 \%$ of $\mathrm{HCO}_{3}{ }^{-}, 72.7 \%$ of $\mathrm{TH}, 39.6 \%$ of TDS, and $32.8 \%$ of $\mathrm{K}^{+}$), agricultural nonpoint pollution $\left(51.4 \%\right.$ of TDS, $56.5 \%$ of $\mathrm{K}^{+}$, and $35.5 \%$ of $\mathrm{NO}_{3}{ }^{-}$), and industrial wastewater and urban nonpoint pollution $(78.6 \%$ of $\mathrm{Fe}, 50.5 \%$ of $\mathrm{Mn}, 55.7 \%$ of $\mathrm{COD}$, and $36.5 \%$ of $\mathrm{SO}_{4}{ }^{2-}$ ).

Based on the results of our study, the point sources (domestic sewage and industrial wastewater) remain the most critical groundwater pollution sources (especially in the dry season, where contribution proportion of point source was 77.5\%) in the Ye River area of China. Therefore, local governments should act to strengthen the sewage treatment infrastructure and also pass strict legislation to prohibit the substandard discharge of sewage and wastewater. Agricultural nonpoint pollution was also an important source of groundwater contamination in the flood season; thus, local government should pursue management of fertilization strategies - such as soil formula fertilization-to increase the efficiency of nitrogen uptake by plants. Implementing the abovementioned measures in a timely way can prevent an increase in the nitrate levels in the Ye River basin.

\subsubsection{Uncertainty analysis}

In this study, a PMF model was used to quantify the contribution of the three factors (sources) to the water-quality variables and sampling sites along the Ye River of the Hebei Province, China. However, there are some uncertainties about these results. In general, the uncertainty of solutions mainly arises from three causes: (1) random errors of the 
data matrix, which are introduced by measurement procedures; (2) rotational ambiguity resulting from the fact that multiple PMF solutions can have the same or very close values of object function Q; (3) modeling errors caused by the simplification of the real system [47]. To resolve this, the reliability and robustness of the results obtained from PMF model (base run) were evaluated with error estimation using the BS and DISP methods. A total of 200 run of BS resampling and PMF model fitting were performed, and the size of bootstrap data was set to 95 based on the recommendation of the PMF model. For each bootstrap run, the factors (sources) derived from PMF model were mapped to those of the base run, according to the relationship between their factor contributions. A bootstrap factor was assigned to the base factor, with which it has the lower correlation $\left(R^{2}<0.6\right)$, and it was considered "unmapped". Table 6 showed that more than $85 \%$ of the base factors were reproduced, suggesting that factor profiles of the base run are reliable.

Table 6. Mapping of bootstrap factors to base factors derived from PMF model.

\begin{tabular}{ccccccccc}
\hline \multirow{2}{*}{ Bootstrap } & \multicolumn{4}{c}{ Dry Season } & \multicolumn{3}{c}{ Flood Season } \\
\cline { 2 - 10 } & Factor 1 & Factor 2 & Factor 3 & Unmapped & Factor 1 & Factor 2 & Factor 3 & Unmapped \\
\hline Factor 1 & 195 & 4 & 1 & 0 & 190 & 7 & 3 & 0 \\
Factor 2 & 8 & 188 & 4 & 0 & 9 & 186 & 5 & 0 \\
Factor 3 & 3 & 5 & 192 & 0 & 3 & 4 & 193 & 0 \\
\hline
\end{tabular}

The DISP analysis could obtain the number of factors, and it is able to judge the stability of the selected PMF solution. Swaps occur when the displacements change factors significantly so that they exchange identities, suggesting that the PMF solution is not well defined [48]. In our study, there was no factor swaps observed under the lowest maximum allowable change of Q (dQ max) level. Therefore, the results of both BS and DISP suggest that the three-factor PMF solution is stable. However, the results of the contribution ratio have some uncertainty, as several basic assumptions of the PMF model are not generally applicable in many cases. For example, the influence of some ions sources of groundwater is restricted to adjacent areas, when the ions might always affect the whole area. The uncertainty ranges for the contributions of the three sources to 14 water-quality variables in the dry and flood season of the Ye River were obtained with error estimation (Table 7).

Table 7. Results of uncertainty analysis for factor contributions ratio (\%) to 14 water-quality parameters in the Ye River of Hebei Province, China using the error estimation methods of displacement of factor elements (DISP).

\begin{tabular}{|c|c|c|c|c|c|c|c|c|c|c|c|c|}
\hline \multirow{3}{*}{ Parameters } & \multicolumn{4}{|c|}{ Factor 1} & \multicolumn{4}{|c|}{ Factor 2} & \multicolumn{4}{|c|}{ Factor 3} \\
\hline & \multicolumn{2}{|c|}{ Dry Season } & \multicolumn{2}{|c|}{ Flood Season } & \multicolumn{2}{|c|}{ Dry Season } & \multicolumn{2}{|c|}{ Flood Season } & \multicolumn{2}{|c|}{ Dry Season } & \multicolumn{2}{|c|}{ Flood Season } \\
\hline & Mean & SD & Mean & SD & Mean & SD & Mean & SD & Mean & SD & Mean & SD \\
\hline $\mathrm{pH}$ & 8.5 & 5.6 & 65.7 & 7.3 & 13.1 & 5.2 & 25.3 & 4.7 & 78.4 & 3.2 & 9.0 & 3.7 \\
\hline TDS & 76.3 & 4.2 & 39.6 & 7.6 & 12.0 & 2.9 & 51.4 & 5.0 & 11.7 & 4.1 & 9.0 & 3.5 \\
\hline $\mathrm{K}^{+}$ & 63.5 & 3.6 & 32.8 & 5.5 & 25.8 & 4.8 & 56.4 & 4.2 & 10.7 & 3.0 & 10.8 & 2.2 \\
\hline $\mathrm{Na}^{+}$ & 74.7 & 4.6 & 49.7 & 7.1 & 11.4 & 4.7 & 32.4 & 4.6 & 13.9 & 3.1 & 17.9 & 3.6 \\
\hline $\mathrm{Ca}^{2+}$ & 75.3 & 5.0 & 70.9 & 6.4 & 13.3 & 5.0 & 19.6 & 4.6 & 11.4 & 3.1 & 9.5 & 2.6 \\
\hline $\mathrm{Mg}^{2+}$ & 76.9 & 4.7 & 69.7 & 6.7 & 12.8 & 4.3 & 15.0 & 4.4 & 10.4 & 3.3 & 15.4 & 3.5 \\
\hline $\mathrm{HCO}_{3}{ }^{-}$ & 10.7 & 3.4 & 56.0 & 7.0 & 15.9 & 4.7 & 34.4 & 4.5 & 73.4 & 3.0 & 9.6 & 3.7 \\
\hline $\mathrm{Cl}^{-}$ & 73.3 & 3.5 & 54.9 & 6.6 & 11.4 & 5.4 & 28.7 & 4.7 & 15.2 & 2.9 & 16.4 & 2.6 \\
\hline $\mathrm{SO}_{4}^{2-}$ & 59.7 & 3.1 & 50.1 & 4.8 & 28.4 & 5.5 & 13.4 & 3.7 & 11.9 & 3.8 & 36.5 & 2.8 \\
\hline $\mathrm{NO}_{3}{ }^{-}$ & 63.1 & 4.5 & 57.6 & 7.2 & 17.6 & 4.9 & 35.5 & 4.7 & 19.3 & 3.0 & 6.9 & 3.7 \\
\hline $\mathrm{Fe}$ & 7.0 & 7.3 & 19.2 & 2.1 & 73.0 & 14.0 & 2.3 & 6.8 & 20.0 & 9.6 & 78.6 & 6.0 \\
\hline $\mathrm{Mn}$ & 10.3 & 13.4 & 22.1 & 11.7 & 58.2 & 14.6 & 27.4 & 7.3 & 31.5 & 6.7 & 50.5 & 8.4 \\
\hline COD & 58.0 & 4.5 & 32.8 & 7.3 & 32.3 & 2.9 & 11.5 & 4.8 & 9.7 & 4.6 & 55.7 & 3.5 \\
\hline $\mathrm{TH}$ & 75.9 & 4.6 & 72.7 & 7.2 & 12.4 & 4.9 & 17.9 & 4.7 & 11.7 & 3.1 & 9.5 & 3.6 \\
\hline
\end{tabular}




\section{Conclusions}

In this study, spatiotemporal variations in groundwater quality and pollution sources were identified along the Ye River of the Hebei Province, China, using the WQI and PMF model. Overall, the mean concentration of $\mathrm{TH}, \mathrm{SO}_{4}{ }^{2-}$, and $\mathrm{NO}_{3}{ }^{-}$were $626.99,216.47$, and $134.60 \mathrm{mg} / \mathrm{L}$, respectively. Their exceeding standard rates were 78.13, 34.38, and 59.38\%, respectively. The main groundwater hydrochemical type has changed from $\mathrm{HCO}_{3}-\mathrm{Ca}(\mathrm{Mg})$ to $\mathrm{HCO}_{3} \cdot \mathrm{SO}_{4}-\mathrm{Ca}(\mathrm{Mg})$. These data indicated that the groundwater quality was generally affected by anthropogenic activities.

Spatial variation in groundwater quality was mainly affected by land use and showed that the mean concentration of $\mathrm{NO}_{3}{ }^{-}$was higher in the farmland area than in the villages and county area. Temporal variation in groundwater quality was primarily controlled by rainfall, and the mean concentrations of $\mathrm{SO}_{4}{ }^{2-}$ and Fe were higher in the dry season than in the flood season.

Based on the results of WQI, the groundwater quality was better in the flood season than in the dry season due to the diluting effect of rainfall runoff on pollutants. Notably, the groundwater quality of the farmland area was relatively poor because it was affected by multiple pollution sources.

The PMF model results showed that the major groundwater pollution sources were domestic sewage $(52.4 \%)$, industrial wastewater $(24.1 \%)$, and enhanced water-rock interaction induced by intensely exploited groundwater $(23.6 \%)$ in the dry season. Meanwhile in the flood season, they were domestic sewage and water-rock interactions (49.6\%), agricultural nonpoint pollution (26.1\%), and industrial wastewater and urban nonpoint pollution $(24.0 \%)$. The mean contribution of the domestic sewage and industrial sewage to 16 sampling sites in the dry season (1489 and $322.5 \mathrm{mg} / \mathrm{L}$, respectively) was higher than that in the flood season (1158 and $273.6 \mathrm{mg} / \mathrm{L}$, respectively). To sum up, the point sources (domestic sewage and industrial wastewater) remain the most critical groundwater pollution sources in this region. These results indicated that the local governments urgently need to develop a priority strategy to control nitrate contamination and achieve water resource sustainability in the Ye River area. In addition, this study was conducted within one hydrological year; thus, the results of the study may have some uncertainty. Therefore, future studies should carry out a long-time series sampling strategy to further confirm the accuracy of the results.

Author Contributions: Conceptualization, Q.Z. and C.N.; methodology, Q.Z.; software, H.W.; validation, C.N. and Q.Z.; formal analysis, L.X.; investigation, L.X., C.N. and H.W.; resources, H.W.; data curation, L.X.; writing-original draft preparation, L.X. and C.N.; writing-review and editing, L.X. and Q.Z.; visualization, C.N.; supervision, Q.Z.; project administration, Q.Z.; funding acquisition, Q.Z. All authors have read and agreed to the published version of the manuscript.

Funding: This work was supported by the projects of the National Natural Science Foundation of China, grant number 41807190; the Belt and Road Fund on Water and Sustainability, China, grant number U2019nkms01; the National Natural Science Foundation of Shanxi Province, grant number 2019JQ-794; and Education Department Foundation of Shanxi Province, grant number 19JK0535.

Institutional Review Board Statement: Not applicable.

Informed Consent Statement: Not applicable.

Data Availability Statement: Not applicable.

Conflicts of Interest: The authors declare no conflict of interest.

\section{References}

1. Hasan, M.S.U.; Rai, A.K. Groundwater quality assessment in the Lower Ganga Basin using entropy information theory and GIS. J. Clean. Prod. 2020, 274, 123077. [CrossRef]

2. Gu, H.; Chi, B.; Li, H.; Jiang, J.; Qin, W.; Wang, H. Assessment of groundwater quality and identification of contaminant sources of Liujiang basin in Qinhuangdao, North China. Environ. Earth Sci. 2015, 73, 6477-6493. [CrossRef]

3. Udeshani, W.A.C.; Dissanayake, H.M.K.P.; Gunatilake, S.K.; Chandrajith, R. Assessment of groundwater quality using water quality index (WQI): A case study of a hard rock terrain in Sri Lanka. Groundw. Sustain. Dev. 2020, 11, 100421. [CrossRef] 
4. Zhang, Q.; Miao, L.; Wang, H.; Hou, J.; Li, Y. How Rapid Urbanization Drives Deteriorating Groundwater Quality in a Provincial Capital of China. Pol. J. Environ. Stud. 2019, 29, 441-450. [CrossRef]

5. Pasten-Zapata, E.; Lenesma-Ruiz, R.; Harter, T.; Ramirez, A.I.; Mahlknecht, J. Assessment of sources and fate of nitrate in shallow groundwater of an agricultural area by using a multi-tracer approach. Sci. Total Environ. 2014, 470-471, 855-864. [CrossRef] [PubMed]

6. Zhang, Q.; Sun, J.; Liu, J.; Huang, G.; Lu, C.; Zhang, Y. Driving mechanism and sources of groundwater nitrate contamination in the rapidly urbanized region of south China. J. Contam. Hydrol. 2015, 182, 221-230. [CrossRef]

7. Jeremiason, J.; Engstrom, D.; Swain, E.; Nater, E.; Johnson, B.; Almendinger, J. Sulfate Addition Increases Methylmercury Production in an Experimental Wetland. Environ. Sci. Technol. 2006, 40, 3800-3806. [CrossRef] [PubMed]

8. Chen, R.; Teng, Y.G.; Chen, H.; Hu, B.; Yue, E.W. Groundwater pollution and risk assessment based on source apportionment in a typical cold agricultural region in Northeastern China. Sci. Total Environ. 2019, 696, 133972. [CrossRef]

9. Huang, G.; Sun, J.; Zhang, Y.; Chen, Z.; Liu, F. Impact of anthropogenic and natural processes on the evolution of groundwater chemistry in a rapidly urbanized coastal area, South China. Sci. Total Environ. 2013, 463-464, 209-221. [CrossRef]

10. Kurunc, A.; Ersahin, S.; Sonmez, N.K.; Kaman, H.; Uz, I.; Uz, B.Y.; Aslan, G.E. Seasonal changes of spatial variation of some groundwater quality variables in a large irrigated coastal Mediterranean region of Turkey. Sci. Total Environ. 2016, 554-555, 53-63. [CrossRef]

11. Zhang, Q.; Wang, H. Assessment of sources and transformation of nitrate in the alluvial-pluvial fan region of north China using a multi-isotope approach. J. Environ. Sci. 2020, 89, 9-22. [CrossRef]

12. Zhang, H.; Xu, Y.; Cheng, S.; Li, Q.; Yu, H. Application of the dual-isotope approach and Bayesian isotope mixing model to identify nitrate in groundwater of a multiple land-use area in Chengdu Plain, China. Sci. Total Environ. 2020, 717, 137134. [CrossRef]

13. Zhang, Q.; Wang, H.; Wang, Y.; Yang, M.; Zhu, L. Groundwater quality assessment and pollution source apportionment in an intensely exploited region of northern China. Environ. Sci. Pollut. Res. 2017, 24, 16639-16650. [CrossRef]

14. Zia, H.; Harris, N.R.; Merrett, G.V.; Rivers, S.M.; Coles, N. Review: The impact of agricultural activities on water quality: A case for collaborative catchment-scale management using integrated wireless sensor networks. Comput. Electron. Agric. 2013, 96, 126-138. [CrossRef]

15. Wu, J.; Li, J.; Teng, Y.G.; Chen, H.Y.; Wang, Y.Y. A partition computing-based positive matrix factorization (PC-PMF) approach for the source apportionment of agricultural soil heavy metal contents and associated health risks. J. Hazard. Mater. 2020, $388,121766$. [CrossRef]

16. Khairy, M.A.; Lohmann, R. Source apportionment and risk assessment of polycyclic aromatic hydrocarbons in the atmospheric environment of Alexandria, Egypt. Chemosphere 2013, 91, 895-903. [CrossRef]

17. Schaefer, K.; Einax, J.W. Source Apportionment and Geostatistics: An Outstanding Combination for Describing Metals Distribution in Soil. Clean-Soil Air Water 2016, 44, 877-884. [CrossRef]

18. Zhang, Q.; Wang, L.; Wang, H.; Zhu, X.; Wang, L. Spatio-Temporal Variation of Groundwater Quality and Source Apportionment Using Multivariate Statistical Techniques for the Hutuo River Alluvial-Pluvial Fan, China. Int. J. Environ. Res. Public Health. 2020, 17, 1055. [CrossRef] [PubMed]

19. Gholizadeh, M.H.; Melesse, A.M.; Reddi, L. Water quality assessment and apportionment of pollution sources using APCS-MLR and PMF receptor modeling techniques in three major rivers of South Florida. Sci. Total Environ. 2016, 566-567, 1552-1567. [CrossRef]

20. Paatero, P.; Tapper, U. Positive matrix factorization: A non-negative factor model with optimal utilization of error estimates of data values. Environmetrics 2010, 5, 111-126. [CrossRef]

21. Perrone, M.G.; Larsen, B.R.; Ferrero, L.; Sangiorgi, G.; Gennaro, G.D.; Udisti, R.; Zangrando, R.; Gambaro, A.; Bolzacchini, E. Sources of high $\mathrm{PM}_{2.5}$ concentrations in Milan, Northern Italy: Molecular marker data and CMB modelling. Sci. Total Environ. 2012, 414, 343-355. [CrossRef] [PubMed]

22. Yan, Y.; He, Q.; Guo, L.; Li, H.; Zhang, H.; Shao, M.; Wang, Y. Source apportionment and toxicity of atmospheric polycyclic aromatic hydrocarbons by PMF: Quantifying the influence of coal usage in Taiyuan, China. Atmos. Environ. 2017, 193, 50-59. [CrossRef]

23. Hu, W.; Wang, H.; Dong, L.; Huang, B.; Holm, P.E. Source identification of heavy metals in peri-urban agricultural soils of southeast China: An integrated approach. Environ. Pollut. 2018, 237, 650-661. [CrossRef] [PubMed]

24. Ren, C.; Zhang, Q.; Wang, H.; Wang, Y. Characteristics and source apportionment of polycyclic aromatic hydrocarbons of groundwater in Hutuo River alluvial-pluvial fan, China, based on PMF model. Environ. Sci. Pollut. Res. 2020, 28, 9647-9656. [CrossRef]

25. Wang, J.F.; Wu, T.L. Analysis on runoff variation characteristics in the Yehe River catchment under the effect of climate change. J. Shanxi Norm. Univ. Nat. Sci. Ed. 2019, 33, 62-67.

26. Ren, C.B.; Zhang, Q.Q.; Wang, H.W.; Wang, Y. Identification of Sources and Transformations of Nitrate in the Intense Human Activity Region of North China Using a Multi-Isotope and Bayesian Model. Int. J. Environ. Res. Public Health. 2021, $18,8642$. [CrossRef]

27. Ministry of Natural Resources of the People's Republic of China (MNRPRC). Standard for Groundwater Quality, (GB/T14848-2017); General Administration of Quality Supervision, Inspection and Quarantine of the People's Republic of China: Beijing, China, 2017. 
28. World Health Organization. Guidelines for Drinking-Water Quality, 4th ed.; World Health Organization: Geneva, Switzerland, 2011.

29. Boateng, T.K.; Opoku, F.; Acquaah, S.O.; Akoto, O. Groundwater quality assessment using statistical approach and water quality index in Ejisu-Juaben Municipality, Ghana. Environ. Earth Sci. 2016, 75, 489. [CrossRef]

30. Petitt, M.; Fracchiolla, D.; Aravena, R.; Barbieri, M. Application of isotopic and geochemical tools for the evaluation of nitrogen cycling in an agricultural basin, the Fucino Plain, Central Italy. J. Hydrol. 2009, 372, 124-135. [CrossRef]

31. Yan, J.; Chen, J.; Zhang, W. Study on the groundwater quality and its influencing factor in Songyuan City, Northeast China, using integrated hydrogeochemical method. Sci. Total Environ. 2021, 773, 144958. [CrossRef]

32. Lin, C.Y.; Abdullah, M.H.; Praveena, S.M.; Yahaya, A.H.; Musta, B. Delineation of temporal variability and governing factors influencing the spatial variability of shallow groundwater chemistry in a tropical sedimentary island. J. Hydrol. 2012, 432, 26-42. [CrossRef]

33. Moran, J.; Ramos-Leal, J.A.; Mahlknecht, J.; Santacruz-DeLetp, G.; Romero, F.M.; Fuentes Rivas, R.; Mora, A. Modeling of groundwater processes in a karstic aquifer of Sierra Madre Oriental, Mexico. Appl. Geochem. 2018, 95, 97-109. [CrossRef]

34. Ren, C.; Zhang, Q. Groundwater Chemical Characteristics and Controlling Factors in a Region of Northern China with Intensive Human Activity. Int. J. Environ. Res. Public Health 2020, 17, 9126. [CrossRef]

35. Gallay, M.; Martinez, J.M.; Allo, S.; Mora, A.; Cochonneau, G.; Gardel, A.; Doudou, J.C.; Sarrazin, M.; Chow, T.F.; Laraque, A Impact of land degradation from mining activities on the sediment fluxes in two large rivers of French Guiana. Land Degrad. Dev. 2018, 29, 4323-4336. [CrossRef]

36. Zhou, F.; Huang, G.H.; Guo, H.; Zhang, W.; Hao, Z. Spatio-temporal patterns and source apportionment of coastal water pollution in eastern Hong Kong. Water Res. 2007, 41, 3429-3439. [CrossRef]

37. Haldar, K.; Kujawa-Roeleveld, K.; Dey, P.; Bosu, S.; Rijnaarts, H.H.M. Spatio-temporal variations in chemical-physical water quality parameters influencing water reuse for irrigated agriculture in tropical urbanized deltas. Sci. Total Environ. 2019, 708, 134559. [CrossRef]

38. Xue, D.; Botte, J.; Baets, B.D.; Accoe, F.; Nestler, A.; Taylor, P.; Cleemput, O.V.; Berglund, M.; Boeckx, P. Present limitations and future prospects of stable isotope methods for nitrate source identification in surface- and groundwater. Water Res. 2009, 43, 1159-1170. [CrossRef]

39. Jin, Z.; Qin, X.; Chen, L.; Jin, M.; Li, F. Using dual isotopes to evaluate sources and transformations of nitrate in the West Lake watershed, eastern China. J. Contam. Hydrol. 2015, 177, 64-75. [CrossRef]

40. Juahir, H.; Zain, S.M.; Yusoff, M.K.; Hanidza, T.I.T.; Armi, A.S.M.; Toriman, M.E.; Mokhtar, M. Spatial water quality assessment of Langat River Basin (Malaysia) using environmetric techniques. Environ. Monit. Assess. 2011, 173, 625-641. [CrossRef]

41. Gammons, C.H.; Poulson, S.R.; Henderson, T.H. Using stable isotopes (S, O) of sulfate to track local contamination of the Madison karst aquifer, Montana, from abandoned coal mine drainage. Appl. Geochem. 2013, 31, 228-238. [CrossRef]

42. Torres-Martinez, J.A.; Mora, A.; Knappett, P.S.K.; Ornelas-Soto, N.; Mahlknecht, J. Tracking nitrate and sulfate sources in groundwater of an urbanized valley using a multi-tracer approach combined with a Bayesian isotope mixing model. Water Res. 2020, 182, 115962. [CrossRef]

43. Zhang, Q.Q.; Wang, H.W.; Lu, C. Tracing sulfate origin and transformation in an area with multiple sources of pollution in northern China by using environmental isotopes and Bayesian isotope mixing model. Environ. Pollut. 2020, 265, 115105. [CrossRef]

44. Qin, R.; Wu, Y.; Xu, Z.; Xie, D.; Zhang, C. Assessing the impact of natural and anthropogenic activities on groundwater quality in coastal alluvial aquifers of the lower Liaohe River Plain, NE China. Appl. Geochem. 2013, 31, 142-158. [CrossRef]

45. Jiang, Y.; Wu, Y.; Groves, C.; Yuan, D.; Kambesis, P. Natural and anthropogenic factors affecting the groundwater quality in the Nandong karst underground river system in Yunan, China. J. Contam. Hydrol. 2009, 109, 49-61. [CrossRef]

46. Lee, J.Y.; Kim, H.; Kim, Y.; Han, M. Characteristics of the event mean concentration (EMC) from rainfall runoff on an urban highway. Environ. Pollut. 2011, 159, 884-888. [CrossRef] [PubMed]

47. Hu, Y.N.; He, K.L.; Sun, Z.H.; Chen, G.; Cheng, H. Quantitative source apportionment of heavy metal(loid)s in the agricultural soils of an industrializing region and associated model uncertainty. J. Hazard. Mater. 2020, 391, 122244.

48. Brown, S.G.; Eberly, S.; Paatero, P.; Norris, G.A. Methods for estimating uncertainty in PMF solutions: Examples with ambient air and water quality data and guidance on reporting PMF results. Sci. Total Environ. 2015, 518, 626-635. [CrossRef] [PubMed] 